DOI: https://doi.org/10.18371/fp.2(34).2019.178498

УДК 330.341.1:336:338.43

\title{
ІННОВАЦІЙНИЙ ТА ФІНАНСОВИЙ РЕСУРСНИЙ ПОТЕНЦІАЛ АГРАРНИХ ПІДПРИЕМСТВ
}

\author{
КОВТУН Валентина Андріївна \\ к. с.-2. н, дочент \\ дочент кафедри економіки та фінансів \\ ДВНЗ «Херсонський державний аграрний університет» \\ ORCID ID: http://orcid.org/0000-0002-4275-026X \\ e-mail:vak2901@ukr.net
}

Анотація. Для ефективного функціонування $i$ забезпечення конкурентоспроможності аграрних підприємств необхідно якісно розвивати матеріально-технічні, структурно-функиіональні, соиіально-трудові та інші елементи потенціалу. Головне місие в цььому належить оиіниі та ефективному використанню саме інновачійному та фінансовому ресурсного потенціалу аграрного підприємства як основи для успішного розвитку системи.

Ключові слова: інновачійний, фінансовий ресурсний потенціал, аграрне підприємство.

Постановка проблеми. Інноваційний розвиток є невід'ємною і активною частиною всіх сфер життєдіяльності суспільства. Значення інноваційного розвитку для регіонів важко переоцінити: тільки через інновації можна забезпечити конкурентоспроможність продукції як на вітчизняному, так і на світовому ринку. Ефективне використання інновацій стає вирішальним фактором соціально- економічного розвитку і розв'язання економічних, екологічних, соціальних та інших проблем.
Аннотация. Для эффрективного функционирования и обеспечения конкурентоспособности аграрных предприятий необходимо качественно развивать материальнотехнические, структурно-функциональные, сочиально-трудовые и другие элементы потеничиала. Главное место в этом принадлежит оценке и эффективному использованию именно финансового ресурсного потенциала аграрного предприятия как основы для успешного развития системы.

Ключевые слова: инновачионный, финансовый ресурсный потенцииал, аграрное предприятие.

Аналіз останніх джерел і публікацій вказує, що вивченням ефективності використання інноваційного та фінансового ресурсного потенціалу займалися такі вчені: Байдала Н.М., Бульда C.О., Воронкова А.Е., Гавва В.Н., Грицаєнко Г.I., Довденко В.I., Должанський І.3., Іванілов О.С., Карюк B.I., Краснокутська Н.С., Коваль О.М., Маршалок М.С., Смерічевська С.В., Ульянченко О.В., Федонін О.С., Чухрай Н.I., тощо.

Виокремлення невиділених рішень частини детальних проблем недостатний рівень досліджень, щодо елемен- 
тів структури інноваційного потенціалу та ефективного його фінансового забезпечення та використання.

Мета статті - на основі дослідження теоретико-методичних та аналітичних аспектів ресурсного потенціалу аграрного підприємства сформулювати та обгрунтувати комплекс заходів спрямованих на підвищення основних його складових інноваційного та фінансового виду.

Виклад основних результатів. Ресурсний потенціал підприємства - це складна економічна категорія яка включає оцінку використання таких основних видів ресурсів як: трудові, природні, матеріальні, фінансові та інформаційні. Він є об'єктивною умовою здійснення виробництва і відображає витратну сторону виробничого процесу.

Ресурсний потенціал характеризується кількістю, якістю та структурою ресурсів, незбалансованість кількісних i якісних характеристик яких викликає зниження виробничого та економічного потенціалу всього народного господарства. У результаті проведеного вивчення і систематизації різних наукових поглядів, можна прийти до висновку, що під ресурсним потенціалом підприємства варто розуміти сукупність наявних видів ресурсів, сполучених між собою, використання яких дозволяє досягти економічного ефекту. Ресурсний потенціал підприємства являє собою сукупність таких основних складових як матеріальний, нематеріальний, кадровий, інноваційний, фінансовий та управлінський потенціали.

Однією $з$ найбільш перспективних сфер світового бізнесу сьогодні $є$ сіль- ське господарство. Провідні аграрні підприємства активно шукають та впроваджують високоякісні інноваційні рішення, які здатні підвищити обсяг виробництва та реалізації продукції, іiі продуктивність і ефективність діяльності господарств, що потребує значних фінансових ресурсів [1, c. 76].

Основу інноваційного потенціалу підприємства складають кадрові та матеріально-технічні складові, а також наявність науково-технічної й інтелектуальної власності.

Фінансовий потенціал являє собою обсяг власних, позичених та залучених фінансових ресурсів підприємства, якими воно може розпоряджатися для здійснення поточних і перспективних витрат, а також можливість, здатність та необхідність їх як простого, так і розширеного відтворення 3 метою забезпечення стійкого, динамічного та збалансованого розвитку аграрного підприємства.

Серед основних підходів щодо оцінки ресурсного потенціалу аграрного підприємства виділяють такі: витратний - визначає вартість об'єкта за сумою витрат на його створення та використання; порівняльний - визначає вартість на базі зіставлення з аналогами, що вже були об’єктами ринкових угод; результатний - оцінює вартість об'єкта на засаді величини чистого потоку позитивних результатів від його використання. Необхідно переймати досвід передових підприємств зарубіжжя та вітчизняних аграрних виробників 3 подальшим вдосконаленням та адаптацією зарубіжних методів до умов функціонування вітчизняної економіки, це питання $\epsilon$ ще не достат- 
ньо розробленим і потребує нових досліджень як на макро- так і на мікрорівні.

Успіх аграрної діяльності визначається правильно обраною стратегією управління ресурсним потенціалом підприємства. Технологія управління ресурсним потенціалом аграрного підприємства включає такі етапи: оцінка структури, динаміки i ефективності використання та його частки на ринку; оцінку його конкурентоспроможності; аналіз його резервів і витрат ; вибір стратегії та тактики по підвищенню його конкурентоспроможності; проведення заходів щодо підвищення конкурентоспроможності інноваційного та фінансового ресурсного потенціалу, виходячи з обраної тактики та стратегіï.

Оцінка фінансової складової ресурсного потенціалу аграрного підприємства полягає у визначенні в грошовому виразі вартості, що може бути найбільш імовірною ціною. Вона дає змогу оцінити: ступінь залучення ресурсів у господарський оборот; ступінь використання активної частини потенціалу; ефективність ресурсів, вкладених у формування і розвиток аграрного підприємства. Найефективнішим та найадекватнішим критерієм оцінки потенціалу аграрного підприємств є ринкова вартість [2, с. 24].

Інноваційний потенціал розглядається як: сукупність ресурсів, необхідних для здійснення інноваційної діяльності; сукупність активів, що використовуються в інноваційній діяльності; можливості підприємства, що визначають обсяги, терміни, кількість і якість його інноваційної діяльності; здатність підприємства проявляти ін- новаційну активність; міра готовності підприємства до здійснення інноваційної активності; складна динамічна система, що здійснює інноваційну діяльність; характеристика потоку нововведень; складова інтелектуального потенціалу; певна структура його складових; одна $з$ трьох складових інноваційного простору. Він є складною динамічною системою генерування, накопичення i трансформування наукових, управлінських ідей та науковотехнічних, маркетингових результатів і інноваційні продукти на основі здійснення безперервного управління аграрним підприємством.

Основу інноваційного потенціалу підприємства складають кадрові та матеріально-технічні складові, а також наявність науково-технічної й інтелектуальної власності. Особливо важливою $є$ наявність кадрів - спеціалістів i вчених, що забезпечують інноваційний процес новими знаннями, ідеями, винаходами, ноу-хау, новими технологіями [3, с. 6].

Послідовна активізація інноваційної діяльності аграрного підприємства за всіма напрямами функціонування дозволяє одержувати нові технологічні процеси, продукцію або форми організації та управління виробництвом, що забезпечує досягнення i зміцнення конкурентних позицій на ринку та вплив на ринкову ситуацію завдяки реалізації інновацій. При цьому функціонування підприємства у довгостроковій перспективі пов'язано з формуванням стратегії розвитку, орієнтованої на посилення інноваційної активності. Формування означеної стратегії являє собою процес прийняття управлінського рішення щодо змісту функ- 
ціональних стратегій такого роду та пріоритетності їх фінансування 3 метою забезпечення конкурентних переваг на ринку.

Оцінку інноваційного потенціалу підприємства доцільно здійснювати в наступній послідовності: аналіз структури інноваційного потенціалу; виявлення ступеня використання внутрішніх інноваційних можливостей підприємства; оцінка рівня інноваційної активності підприємства

Основні напрямки стратегії інноваційного регіонального розвитку є: цільовий ринок, позиція товару, асортимент товару, ціноутворення, реклама, просування товару, стимулювання збуту продукції, маркетингові дослідження. Для цього необхідно здійснити такі заходи: збільшити частку ринку, зробивши ставку на зацікавлених споживачів конкретної продукції; забезпечити привабливість послуг за рахунок збільшення гарантійного терміну експлуатації і надання комплексів послуг; розширити номенклатури послуг і підтримки високої конкурентоспроможності з метою окупації ринкових сегментів. які можуть зайняти конкуренти [4, с.82].

Охарактеризуємо елементи структури інноваційного потенціалу та низький і високий їх рівень:

- організаційна структура - лінійна, лінійно-функціональна та лінійнофункціональна 3 елементами програмно-цільових організаційних утворень, матричні структури, творчі команди;

- технологічна - спеціалізоване виробниче обладнання, жорстко пов'язане в єдиний потік для масового випуску продукції та при високому гнучкі автоматизовані виробничі мо- дулі, зв’язані безрейковою гнучкою транспортною системою;

- дослідно-конструкторська - спеціально спроектовані під даний виробничий процес та універсальний тип, наявність резервних площ, можливість зміни компонування лабораторій, відділів;

- організація праці - індивідуальна, поопераційна, регламентована та бригадна 3 високим рівнем сполучення операцій і професій, вільний вибір чаcy;

- оплата праці - індивідуальна, відрядна та почасово-преміальна, бригадна 3 використанням особистого вкладу;

- переміщення персоналу - мінімальна, в основному за ієрархічною градацією та можливість горизонтальних i вертикальних переміщень згідно 3 вирішуваними завданнями, створення тимчасових бригад;

- стиль управління - авторитарний, мінімум делегування повноважень, жорсткий контроль за виконанням та делегування повноважень, що забезпечує високий ступінь залучення персоналу до розробки рішень, подання ідей;

- система інформування персоналу оперативна інформація про виконання планових завдань певним підрозділом та докладне інформування про діяльність підприємства в цілому, його життя, проблеми та завдання у сфері інновацій;

- психологічний клімат - налаштування на вирішення поточних завдань в рамках свого робочого місця та налаштування на пошук рішень як оперативних, так i довгострокових, як у рамках робочого місця, так і поза його 
межами. Стимулювання інноваційного клімату та інноваційної активності Скрипко Т.О. [5, с. 248].

Бальна оцінка використання підприємством потенціалу кожного $з$ елементів інноваційного потенціалу здійснюється $з$ використанням такої шкали: 0 балів - зовсім не використовується потенціал елементу; 1 бал - низький рівень використання потенціалу елементу; 2 бали - середній рівень використання потенціалу елементу; 3 бали - високий рівень використання потенціалу елементу.

Заключний етап оцінки інноваційного потенціалу передбачує визначення рівня інноваційної активності підприємства за допомогою узагальнюючого показника - коефіцієнту інноваційної активності підприємства, розрахунок якого здійснюється за наступною методикою:

$$
\mathrm{P} \text { ін.акт . }=\sum(\mathrm{Pi} \times \mathrm{xi})
$$

де $\mathrm{P}$ ін.акт. - рівень інноваційної активності підприємства; Pi - експертна оцінка використання і-того елементу інноваційного потенціалу, бали; Wi коефіцієнт вагомості і-того елементу інноваційного потенціалу.

Оцінку рівня інноваційної активності підприємства доцільно здійснювати за наступною шкалою: від 0 до 4,0 - низький рівень, від 4,1 - до 8,0 - середній рівень, від 8,1до 11,55- високий рівень [6, с 194].

Фінансовий потенціал аграрного підприємства це обсяг власних, позичених та залучених фінансових ресурсів підприємства, якими воно може розпоряджатися для здійснення поточних і перспективних витрат, а також можливість, здатність та необхідність їх як простого, так і розширеного відтво- рення $з$ метою забезпечення стійкого, динамічного та збалансованого розвитку підприємства [7, с . 5].

Своєчасна та об'єктивна оцінка фінансового стану аграрного підприємств в сучасних умовах має велике значення, що дає визначити потенційні можливості збільшення доходів, які можна виявити тільки на підставі своєчасного об'єктивного аналізу фінансового стану. Оцінку фінансового потенціалу підприємства проводять за такими основними групами показників: показники оцінки ліквідності ( коефіцієнти покриття, швидкої та абсолютної ліквідності, частка оборотних засобів та виробничих запасів, а також вартість робочого капіталу); показники оцінки фінансової стійкості (коефіцієнти автономії, фінансової залежності та стійкості, забезпечення власними оборотними засобами, фінансування та фінансової стійкості, концентрації залученого капіталу та поточних зобов'язань); показники оцінки ділової активності; показники оцінки ефективності господарювання [8].

Ліквідність стосується наявності грошових коштів у найближчому майбутньому після виконання фінансових зобов'язань певного періоду.

Фінансова стійкість - це надійно гарантована платоспроможність, рівновага між власними та залученими засобами, незалежність від випадковостей ринкової кон'юнктури і партнерів, довіра кредиторів і інвесторів та рівень залежності від них, наявність такої величини прибутку, який би забезпечив самофінансування.

Фінансова стійкість підприємства передбачає, що ресурси, вкладені в підприємницьку діяльність, повинні 
окупитись за рахунок грошових надходжень від господарювання, а отриманий прибуток забезпечувати самофінансування та незалежність підприємства від зовнішніх залучених джерел формування активів.

Ділова активність - це комплексна характеристика, яка втілює різні аспекти діяльності підприємства, а тому визначається системою таких критеріїв, як місце підприємства на ринку конкретних товарів, географія ділових відносин, репутація підприємства як партнера, активність іноваційноінвестиційної діяльності, конкурентоспроможність. Таким чином, ділова активність може характеризуватись динамікою показників ефективності виробничо-господарської діяльності в цілому. Позитивна динаміка цих показників сприятиме зміцненню фінансового стану підприємства. Ділова активність підприємства проявляється через розширення ринків збуту продук- ціï, підтримання ділової репутації (іміджу), вихід на ринок праці і капіталу тощо [9, с.138].

Ефективність - це співвідношення результатів (зокрема побічних і непрямих) господарської діяльності 3 витраченими ресурсами: трудовими, матеріальними, природними, фінансовими, основним капіталом тощо. Теорія ефективності розробляє методи вимірювання витрат і результатів функціонування національного господарства та його окремих ланок.

Ефективність розкриває характер причинно-наслідкових зв'язків виробництва. Вона показує не сам результат, а те якою ціною він був досягнутий. Тому ефективність найчастіше характеризується відносними показниками, що розраховуються на основі двох груп характеристик (параметрів) - результату і витрат (табл.1).

Таблиця 1

Показники ефективності господарювання аграрних підприємств

\begin{tabular}{|c|c|}
\hline Показники & Алгоритм розрахунку \\
\hline Рентабельність продукції & $P n=B \Pi / C p n \times 100$ \\
\hline Рентабельність операційної діяльності & Род $=\Pi \circ \partial / O B \times 100$ \\
\hline Рентабельність звичайної діяльності & $P_{3} \partial=\Pi_{3} \partial / 3 B \times 100$ \\
\hline Рентабельність господарської діяльності & Ргд=ВП/Пзд.заг. х100 \\
\hline Коефіцієнт покриття виробничих витрат & Кn.вв=ЧД/Сpn \\
\hline Коефіцієнт окупності виробничих витрат & Кок.вв=Срп/ЧД \\
\hline Валова рентабельність продажу & Рв.nn=ВП/ЧД $\times 100$ \\
\hline Чиста рентабельність продажу продукції & Рч.nn=ЧП/ЧД х100 \\
\hline Рентабельність доходу від операційної діяльності & Рд.од $=\frac{\text { Под }}{(Ч Д+І н . о д)} \times 100$ \\
\hline Рентабельність підприємства & $P n-b a=\frac{\text { ЧП }}{\text { ВАсp }} \times 100 \times 100$ \\
\hline
\end{tabular}


Закінчення табл. 1

\begin{tabular}{|c|c|}
\hline \multirow[t]{2}{*}{ Рентабельність власного капіталу } & $\underline{\text { Пдо_опод }}$ \\
\hline & $P_{6 \kappa}=\quad B K c p \quad \mathrm{x} 100$ \\
\hline \multirow[t]{2}{*}{ Рентабельність залученого капіталу } & Пдо_опод \\
\hline & $P_{3 \kappa}=\quad 3 K c p \quad \mathrm{x} 100$ \\
\hline \multirow[t]{2}{*}{ Рентабельність необоротних активів } & Пдо_опод \\
\hline & Pнa $=$ HAcp $\mathrm{x} 100$ \\
\hline \multirow[t]{2}{*}{ Рентабельність оборотних активів } & Пдо_опод \\
\hline & Роб.a= ОАср $\mathrm{x} 100$ \\
\hline Коефіцієнт окупності активів & Kn. $a=$ ЧП $\sum A$ \\
\hline Коефіцієнт окупності власного капіталу & Кок.вк $=$ ЧП $\sum B К$ \\
\hline Коефіцієнт покриття власного капіталу & Кn.вк=ЧД/ $\sum B К$ \\
\hline Коефіцієнт покриття активів & Kn. $a=4 Д / \sum A$ \\
\hline
\end{tabular}

Джерело: [9, с.189]

Умовні позначення: ВП - валовий прибуток; Срп - собівартість реалізованої продукції; Под - Прибуток від операційної діяльності; ОВ - операційні витрати; Пзд - прибуток від звичайної діяльності; ЗВ - витрати від звичайної діяльності; Пзд_заг - прибуток від звичайної діяльності загальний; ВП - витрати підприємства; ЧД чистий дохід; ЧП - чистий прибуток; Ін.од - інші операційні доходи; ВАср - середньорічна вартість активів; Пдо опод - прибуток до оподаткування; ВКср - середньорічна вартість власного капіталу; ЗКср - середньорічна вартість залученого капіталу; НАср - середньорічна вартість необоротних активів; ОАср - середньорічна вартість оборотних активів; $\sum \mathrm{A}$ - сума активів; $\sum$ ВК - сума власного капіталу [9, c.189].

Для прийняття раціональних управлінських рішень у сільському господарстві сучасні технології дозволяють виявляти недоліки та ризики в техно- логічних процесах. Впроваджуючи в діяльність аграрних підприємств інноваційні технології, інвестиційні кошти працюють не тільки на стратегічні плани, а й на тактичні можливості, заощаджуючи земельні, виробничі, трудові та фінансові ресурси сільського господарства. Економічний ефект від запровадження мінімального обробітку грунту в 2020 році становитиме 6,3 млрд. грн. Підвищення продуктивності культур за прогнозними показниками приведе до збільшення їхньої врожайності в $1,5-2,7$ разу в 2020 році порівняно з 2010 роком.

Поліпшення агротехнічних робіт забезпечить заощадження мінеральних добрив на 13,9 млрд. грн. на рік. Грунтово-кліматичні умови України дають змогу значно розширити обсяги органічного землеробства, які за експертними оцінками можуть досягти 7\% сільськогосподарських угідь у 2020 році. Завдяки впровадженню інтелектуальних технологій відбудеться збі- 
льшення виробництва валової продукції тваринництва у 2020 році до 83,4 млрд грн, що майже в 2 рази більше проти 2010 року, а також збільшення обсягів виробництва м'яса в забійній масі у 2020 році до 4365 тис. т., темп приросту цього показника буде становити $112,0 \%$ [10].

Висновки. Зважаючи на сучасні виклики конкурентного середовища та світової глобалізації для забезпечення розвитку вітчизняних аграрних підприємств нагальним стає впровадження інновацій. Тільки досягнення світового рівня інноваційної активності є для аграрних підприємств його конкурентоспроможністю. Отже, розробка програми інноваційного розвитку i, як наслідок, відповідної стратегії $є$ базою формування конкурентних переваг i стійкого фінансового стану вітчизняних аграрних підприємств.

\section{Список використаної літератури}

1. Ковтун В.А. Пріоритети та складові стратегії інноваційного регіонального розвитку. Розвиток підприємницької діяльності в умовах глобальних та інтеграційних процесів: матер. Міжнар. наук.-практ. інт. конф. Херсон: ХДАУ, 2019. C. 75-78.

2. Прохорова В.В. Критичний огляд методичних підходів до оцінки ресурсного потенціалу промислових підприємств у сучасних економічних умовах: монографія. Економіка та управління, 2012. №6. С. 22-27.

3. Іванілов О.С. Інноваційний потенціал підприємства. Економіка, фінанси, право, 2011. №12. С. 5-7.

4. Орлова В.М. Стратегія інноваційного розвитку підприємства. Економічний нобелівський вісник, 2015. № 1 (8). С. 79-85.

5. Скрипко Т.О. Інноваційний менеджмент: підруч. К.: Знання, 2011. 423 с.

6. Коваль Н.В. Інноваційний потенціал підприємства: сутність та структура: монографія. Білоцерківський НАУ, 2012. 318 с.

7. Грицаєнко Г.І. Аграрний ресурсний потенціал. Актуальні проблеми економіки, 2012. 6 с.

8. Коваль О.М. Оптимізація ефективності використання ресурсного потенціалу сільськогосподарських підприємств України. Національна бібліотека України імені В. I. Вернадського: веб-сайт. URL: http//www.nbuv.ua/portal/chem..biol /nvnau/2012-154-1/10kom.pdf.

9. Тютюнник Ю. М., Дорогань-Писаренко Л. О., Тютюнник С. В. Т98 Фінансовий аналіз : навч. посіб. Полтава : ПДАА, 2016. 430 с. 
10. Ковтун В.А. Роль інтелектуальних технологічних рішень для ефективного використання ресурсів сільського господарства. Східна Європа: економіка, бізнес та управління, 2019, №1(18). URL: http://www.easterneurope-ebm.in.ua/182019-ukr. 